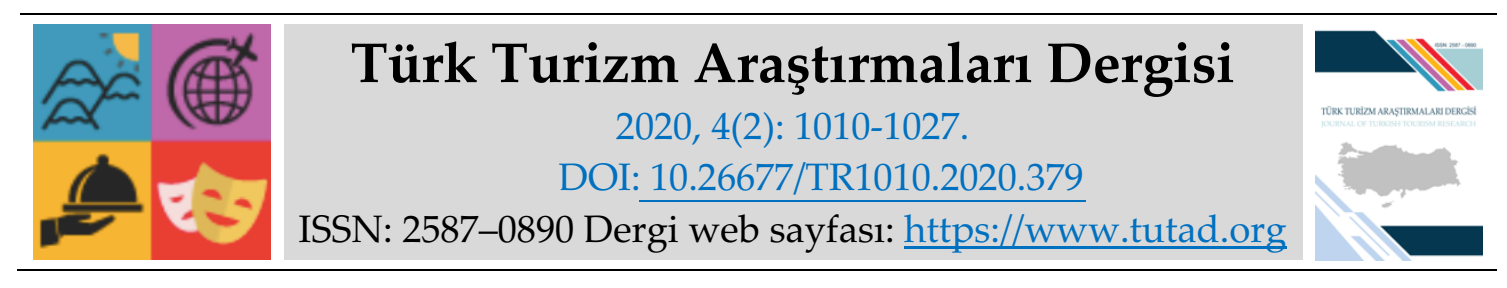

ARASTIRMA MAKALESİ

\title{
İnanç Turizmi Alanındaki Çalışmaların Bibliyometrik Analizi
}

Arş. Gör. Burcu KARASAKALOĞLU, Alanya Alaaddin Keykubat Üniversitesi, Turizm Fakültesi, Antalya, e-posta: burcu.karasakaloglu@alanya.edu.tr

ORCID: https://orcid.org/0000-0002-1765-8138

\section{$\ddot{O} \mathbf{z}$}

Bu çalışmada, inanç turizmi ile ilgili 1998-2019 yılları arasında ulusal literatürde yayımlanan makale ve tezlerin bibliyometrik analiz yöntemi ile incelenmesi ve bu alanda çalışmak isteyen araştırmacılara rehber olması amaçlanmıştır. Çalışmada, Yükseköğretim Kurulu (YÖK) Akademik Arama veri tabanında "inanç turizmi" kelimesi Türkçe ve İngilizce dillerinde yazılarak taranmıştır. Yapılan araştırmada 52 makale ve 46 tez olmak üzere toplam 98 yayına ulaşılmıştır. İnanç turizmine ilişkin araştırmaların; yıllara göre dağılımı, çalışmanın türü, yazarın bağlı bulunduğu kurum, araştırma alanı, araştırma konusu, araştırma yaklaşımı ve tasarımı, araştırma yöntemi, araştırma analizleri, veri toplama teknikleri, örneklem grubu ve örneklem seçme yöntemi konuları incelenmiştir. Veriler istatistik programına girilmiş ve çalışmada verilerin frekans analizi ve yüzdelik dilimleri hesaplanarak inanç turizmi ile ilgili araştırmalar bibliyometrik analiz ile incelenmiştir. Çalışmada, makaleler içerisinde en çok araştırılan konunun dini yerlerin inanç turizmi kapsamında değerlendirilmesi üzerine olduğu, tezlerde ise inanç turizmine yönelik yerel halkın bakış açısı ve bir bölgenin inanç turizmi potansiyeli konularının en çok araştırıldığı sonucuna ulaşılmıştır. Makalelerde çoğunlukla nitel araştırma yöntemleri tercih edilirken tezlerde nicel araştırma yöntemlerinin tercih edildiği belirlenmiştir. Nicel araştırma yöntemlerini kullanan makale ve tezlerin ise genellikle temel düzey istatistik analizlerinden yararlandığı sonucuna ulaşılmıştır.

Anahtar Kelimeler: Turizm, İnanç Turizmi, Bibliyometrik Analiz.

Makale Gönderme Tarihi: 03.02.2020

Makale Kabul Tarihi: 15.04.2020

\section{Önerilen Atıf:}

Karasakaloğlu, B. (2020). İnanç Turizmi Alanındaki Çalışmaların Bibliyometrik Analizi, Türk Turizm Araştırmaları Dergisi, 4(2): 1010-1027.

(C) 2020 Türk Turizm Araştırmaları Dergisi. 


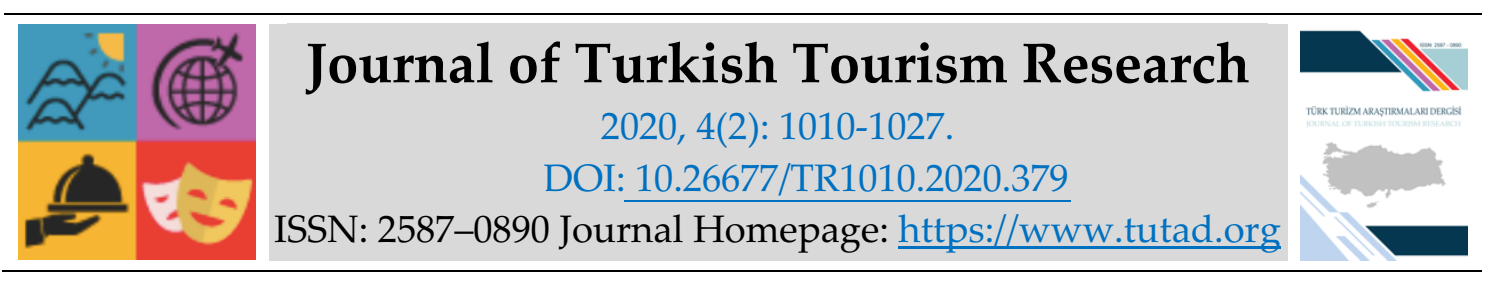

\title{
$\underline{\text { RESEARCH PAPER }}$
}

\section{Bibliometric Analysis of Religious Tourism Studies}

Research Assistant Burcu KARASAKALOĞLU, Alanya Alaaddin Keykubat University, Faculty of Tourism, Antalya, e-mail: burcu.karasakaloglu@alanya.edu.tr

ORCID: https://orcid.org/0000-0002-1765-8138

\begin{abstract}
In this study, it is aimed to examine bibliometric analysis of articles and graduate theses published between 1998-2019 on religious tourism in Turkish literature and to guide researchers who want to work in this field. In this regard, the word "religious tourism" was searched in Turkish and English languages in the Academic Search database of the Council of Higher Education. In research, 46 of 98 publications consist of graduate thesis and 52 articles were examined. The data were analyzed by statistical software to make frequency and percentage analysis and the studies related to religious tourism were examined with bibliometric analysis. The studies related to religious tourism were analyzed in terms of the year of publication, type of the study, institution, research field and subject, research approach and design, research method, research analysis, data collection techniques, sample group and sample selection methods were examined. The most researched subject in the articles was on the evaluation of religious places within the scope of religious tourism, and in the theses the most researched subjects were the religious tourism potential of a region and the local people's perspective on religious tourism. In the study, it was found that in the articles were preferred mostly qualitative research methods, whereas in graduate theses mostly quantitative research methods were preferred. It is concluded that articles and theses using quantitative research methods generally benefit from basic level statistical analysis.
\end{abstract}

Keywords: Tourism, Religious Tourism, Bibliometric Analysis.

Received: 03.02 .2020

Accepted: 15.04 .2020

\section{Suggested Citation:}

Karasakaloğlu, B. (2020). Bibliometric Analysis of Religious Tourism Studies, Journal of Turkish Tourism Research, 4(2): 1010-1027.

(c) 2020 Türk Turizm Araştırmaları Dergisi. 


\section{GíRiş}

Günümüzde sanayileşme, çalışma düzeni ve değişen yaşam koşulları gibi etkenler ile kişiler daha sık seyahat etme imkânına sahip olmuştur. Kişilerin seyahat etme motivasyonlarının ne olduğuna ve hangi ihtiyaçlardan dolayı seyahat ettiğine yönelik sorulara zaman içerisinde yanıt aranmaya çalışılmıştır (İbiş ve Batman, 2018: 251). Bu bağlamda, turistlerin seyahat etme nedenleri üzerine yapilan araştırmalarda, turistlerin sosyal güdüler nedeni ile seyahat etmeye yöneldiği (Correia vd., 2007: 2), rutin çalışma hayatından uzaklaşma, seyahatten hoşlanma ve sosyal kabul görme gibi nedenlerin seyahat etme kararını etkilediği (Lundberg, 1971: 70), ayrıca seyahat etme ve destinasyon seçiminde ise ulaşım, konaklama ve tur operasyonundaki koşulların etkili olduğu belirtilmiştir (Papatheodorou, 2001: 165). Seyahat etme niyetinin, bir eyleme yol açan ve motivasyonu davranışa dönüştüren zihinsel bir süreç olduğu şeklinde ifade edilmektedir (Jang vd., 2009: 57). Bir başka ifade ile turistlerin seyahat etme niyeti geçmişte yaşadıkları deneyimler ile elde ettikleri algılarının sonucudur (Horng vd., 2012: 816). Turistler seyahat etme motivasyonlarının oluşması ile birlikte motivasyonlarına uygun olan çeşitli turistik ürünlere yönelmişlerdir (Benur ve Bramwell, 2015:213; Farmaki, 2012: 185; Bartolomé vd., 2009: 56, Wu vd., 2000: 299). Benzer şekilde boş zaman, gelir artışı ve sosyalleşme isteği gibi birden fazla faktör nedeniyle ortaya çıan farklılık arayışı turizm türlerinde de farklılaşmaya yol açmıştır (Albayrak, 2013: 144). Bu nedenle sadece tatil ve dinlenme amaçlı seyahatlerin yanında av, spor gibi alanlarda ya da yaylalarda vakit geçirme amaçlı seyahat sayısında da artış görülmektedir (Zengin, 2006: 106). Başka bir ifade ile modern dünyada tatil anlayışının değişmesi ile birlikte kıyı turizmin yanında farklı kültürleri tanıma, doğa ile iç içe olma, geçmiş kültürlerin öğelerini yerinde görme ve inanç sistemlerini tanıklık etme ile el sanatları, alışveriş ve eğlence anlayışı gibi nedenler de seyahat etme nedenlerinden sayılmaktadır (Tapur, 2009: 474).

Önemli turizm türlerinden biri olan inanç turizmi kapsamında, dünyada yaklaşık altı yüz milyon ulusal ve uluslararası dini veya inanç amacıyla seyahat yapıldığı tahmin edilmektedir. Bu seyahatlerin \%40'1 Avrupa'da ve \%60'a yakını Asya'da gerçekleşmektedir (Dünya Turizm Örgütü, 2011). Bu bağlamda, her yıl milyonlarca insan, büyük hac yerlerine ve kutsal bölgelere seyahat etmektedir. Yılda yaklaşık 240 milyon kişinin hacca gittiği, çoğunluğunun Hristiyan, Müslüman ve Hindu olduğu tahmin edilmektedir. Dini veya ruhsal motivasyon nedeni ile seyahat eden kişi sayısı son yıllarda giderek artmakta ve uluslararası turizm hareketinin önemli bir bölümünü oluşturmaktadır (Olsen ve Timoty, 2006: 1). Turizm ve din arasındaki karmaşık ilişki göz önüne alındığında, yakın zamana kadar turizm literatüründe inanç turizmine nispeten daha az yer verildiği görüşü hakimdi (Sharpley, 2009: 238). Ancak dünya genelinde inanç merkezlerinin turistik bir faaliyet içerisinde değerlendirilmeye başlanması ile turistleri bu merkezlere gitmeye yönelten motivasyonun ne olduğunun anlaşılmasına yönelik bir ihtiyaç ortaya çıkmıştır (Hughes vd., 2013: 210). Dolayısıyla, inanç turizmine ilişkin akademik ilginin artması, turizm dergilerinde bu konunun çalışılmasına yol açmıştır (Kim vd., 2019: 1). Bu amaçla, söz konusu bu çalışmada, turizm hareketleri içerisinde büyük bir yeri olan inanç turizminin ulusal boyuttaki mevcut durumunun ortaya konması ve ileride bu alanda çalışmak isteyen araştırmacılara ışık tutması hedeflenmiştir. Bu bağlamda Yükseköğretim Kurulu Akademik Arama veri tabanında inanç turizmi ile ilgili yayımlanmış bilimsel çalışmalar bibliyometrik analiz yöntemi ile değerlendirilmiştir.

\section{INANÇ TURIZMI}

Günümüzde, inanç ve hac merkezlerinin canlanması inanç turizminde bir hareketliliğe yol açmakta ve bu durum son zamanlarda araştırmacıların da dikkatini çekmektedir (Verma ve Sarangi, 2019: 296). Turizm, geleneksel olarak, kutsal yerlere seyahat etmek için güçlü bir güdü sonucu din ile yakın bir ilişki içindedir (Henderson, 2003: 447). Hac, uzun bir süre ortak seyahat amacı olmuştur (Shackley, 2006: 94). Ayrıca, inanç turizmi ile anlatılmak istenilenin ne olduğu ve hac görevini yerine getirmekten farklı olup olmadığı konusunda önemli tartışmalar vardır. Hacılar ve inanç turizmine katılan turistler belirli bir süre içinde sürekli yaşadığı yere geri dönmek şartı ile seyahat etmekte ve bu seyahatin motivasyonu 
inanç olarak ifade edilmektedir (Blackwell, 2015: 105). İnanç turizmi; ibadet merkezlerini ziyaret etmenin yanında genel turizm motivasyonu ve ulaşım unsurlarını da bir arada bulundurmaktadır (Alecu, 2010: 60).

İnanç turizmi, bilinen en eski turizm türlerinden birisidir. Orta çağ döneminde de "inanç turizmi" kavramına benzer kavramlar kullanılmıştır. Roma, Kudüs gibi destinasyonlar, bu dönemin önemli inanç merkezleri haline gelmiştir. Kitle turizm hareketlerinin 19. yy'da artması ile birlikte inanç turizmi de yayılmaya başlamıştır (Güzel, 2010: 90). Dünyada yaşanan teknolojik gelişmeler ile bir yerden bir yere gitmek için harcanan zaman giderek kısalmış ve farklı kültürlere sahip uygarlıklar birlikte yaşar hale gelmişlerdir. Ülkemiz açısından değerlendirildiğinde ise Hristiyanlığın ve Museviliğin ilk yıllarında bulundukları bölgelerden baskı gibi farklı nedenlerle Anadolu'ya kadar ilerlemesi Anadolu'da birçok medeniyetin kurulmasını sağlamıştır. Böylelikle Anadolu toprakları İslamiyet ile birlikte zengin bir kültür merkezi haline gelmiştir (Şenol, 2016: 64). Ülkemizde, Hristiyanlığın önemli merkezlerinden olan Efes, İznik, Antakya, İstanbul gibi bölgeler, Hristiyanlık için kutsal kabul edilen inanç merkezlerinden sayılmaktadır. Ayrıca, Hz. İbrahim ve onun soyundan gelen peygamberlerin Şanlıurfa'da yaşaması bu şehrin "Peygamberler Şehri" olarak anılmasını sağlamış ve inanç turizmi merkezi haline gelmiştir. Zaman içerisinde kurulmuş olan birçok sinagog, mabet ve tapınak Anadolu topraklarında bulunmaktadır (Sargin, 2006: 4).

İnsanların sürekli olarak yaşadıkları ve günlük olağan ihtiyaçlarını karşıladıkları yer dışında dini inançlarını tatmin etmek, inandıkları dinin gerekliliklerini yerine getirmek ve inanç çekim merkezlerini görmek amacıyla yaptıkları turistik amaçlı geziler, turizm olgusu içerisinde inanç turizmi olarak ifade edilmektedir (Zengin, 2006: 177). Dini yapıların, bireylerin sınırları aşma kapasitelerini etkilemedeki rolü nedeniyle, zaman içinde seyahat etme motivasyonun din ve dini deneyim anlayışı haline gelmesine yol açmıştır (Hall, 2006: 65). Rinschede'ye (1992: 52) göre inanç turizmi, katılımcıları kısmen ya da tamamen dini nedenlerle seyahat etmeye motive eden turizm türüdür. Dünyanın geneline bakıldığında dinin, insanların inanç açısından önemli yerlere seyahat etmesini sağlayan önemli bir güç olduğuna ve din merkezli destinasyonların küresel turizme çok fazla uyum sağladığına inanılmaktadır (BidzanGekic, Gekic ve Zunic, 2019: 79). İnanç turizmi faaliyetinde bulunan turistler, turistik gezi özelliklerinin yanında kısmi ya da tam olarak hac gerekliliklerini de yerine getirebilmektedir. Turizm ve inanç, turist davranışını etkileyebilmektedir. Örneğin din; destinasyon seçimini, turistik ürün tercihlerini ve olanaklarını etkilemektedir (Weidenfeld ve Ron, 2008: 357).

İnanç turizmi, turizm endüstrisinde en çok büyüyen turizm çeşitlerinden biri olmuştur ancak diğer turizm türlerinden amaç ve motivasyonları bakımından farklılık göstermektedir (Hassan vd., 2015: 84). Shackley (2005: 34) hem ibadet edenlerin hem de ibadet etmeyenlerin kutsal bölgelerde yaşadığ deneyim kalitesini artırmak için inanç turizmini bir hizmet sunumu perspektifi ile nasıl ele alınabileceğini incelemiştir. İnançları doğrultusunda gerekliliklerini yerine getiren hacılar dışındaki inanç turizmi turistleri, dini öneme sahip bir yeri ziyaret etmek için yola çıkan turistler olarak tanımlanmaktadır. Bunlar, dini anlam arayışı yerine kültürel ve tarihi çekicilikler amacıyla inanç merkezlerine seyahat ettikleri için dini amaçlı seyahat edenlerden farklı kabul edilmektedir. Ancak ibadetlerini yerine getiren hacıların yemek yemesi, uyuması ve hedeflerine doğru seyahat etmeleri gerektiği de bir gerçektir. Tüm bu unsurlar turizm alanına aittir. Öte yandan, özellikle inançla motive olmayan turistler, sadece merak için belirli yerleri ziyaret edenler, yaşamın yeni anlamlarını keşfetmeyi, pozitif enerjiler biriktirmeyi amaçlayabilmektedir (Tala ve Padurean, 2008: 243). Puşcaşu (2015: 132), inanç turizmini ekonomik, sosyolojik açıdan ele almış turizm coğrafyası çerçevesinde değerlendirmiştir. İnanç seyahatlerinin yüzyıllardan beri var olduğunu ancak inanç turizminin modern zamanın bir olgusu olduğunu belirtmiştir. Rotherham (2007: 65) ise hac, din ve turizm kavramlarını inceleyerek, İngiltere'de bulunan dini yerlere yapılan ziyaretleri ekonomik yenilenme ve toplumun sürdürülebilirliği açısından incelemiştir. Kiliseler ve camiler gibi birçok dini yerin turizm amacı çerçevesinde ziyaretçi merkezleri olduğunu da belirtmektedir. Örnek vermek gerekir ise, bugün, İstanbul' da bulunan Ayasofya ve Sultanahmet Camii'yi Müslüman olan ve olmayan binlerce kişi 
ziyaret etmektedir. Bu ziyaretlerde ibadet etmek amacının yanında kültürel bir mirası da ziyaret etme amacı taşıabilmektedir.

\section{LITTERATÜR TARAMASI}

Bibliyometri kelimesinin ilk olarak 1969 yılında “Journal of Documentation"da kullanıldığ1 bilinmektedir (Broadus, 1987: 373). Bibliyometri, araştırmacıların karar verme sürecine yardımc1 olmakta ve büyük oranda geçmiş verileri araştırmayı, düzenlemeyi ve analiz etmeyi ifade etmektedir. Bibliyometri analizinde sık kullanılan bazı araçlar ise yazar bağlantıları, kavramsal haritalar, kümeleme, faktör analizi, atıf ve ortak atıf analizidir (Daim vd., 2006: 983). Bibliyometri, matematiğin ve istatistiksel yöntemlerin kitaplara ve diğer iletişim ortamlarına aktarılması şeklinde tanımlanabilir (Pritchard, 1969: 349). Ayrıca, bibliyometrik analiz belirli bir konunun gelişimi ve genel eğilimlerinin belirlenmesi açısından kullanıldığı gibi (Aydın, 2017: 24), akademik kurumların, bilimsel açıdan mevcut durumlarının tespit edilebilmesi amacıyla da uygulanan bilimsel bir yöntemdir (Zencir ve Kozak, 2012: 674).

Turizm alanı incelendiğinde ise turizm bilgisinin yapısı ve gelişimi hakkında bir değerlendirme yapabilmek için turizm alanında yayımlanan akademik dergilerin incelenmesi gerekmektedir. Söz konusu araştırmalarda kullanılan analiz yöntemleri genellikle içerik analizi, atıf analizi, yazarlık ve ortak yazarlık analizi ile sosyal ağ analizi gibi yöntemlerdir (Karagöz ve Kozak, 2014: 48). Bu nedenle turizm alanında yapılan bibliyometrik çalışmalar ile turizmin alt konu başlıklarındaki çalışmalara ilişkin bütünsel bir bakış açısı sağlanması açısından önemlidir (Özel ve Kozak, 2012: 717). Uluslararası literatür incelendiğinde Barrios vd., (2008) turizm ve psikoloji çalışmalarını araştırmış, Hall (2006) ise turizm ve rekreasyon üzerine bibliyometrik çalışmalar yürütmüştür. Ayrıca turizm ve kriz yönetimi (Jiang vd.,2019), yiyecek ve gastronomi (Okumuş vd., 2018), şarap turizmi (Sánchez vd., 2017) ve turizm dergileri (Köseoglu vd., 2015) alanlarındaki çalışmalar ile ilgili bibliyometrik çalışmalar yapılmıştır.

Turizm alanındaki bibliyometri çalışmaları incelendiğinde ise, Kozak (1996: 3) tarafından gerçekleştirilen turizm tezleri bibliyografisi yayımlanmıştır. Bu çalışmada turizm ile ilgili alanlardaki uzmanlık, yüksek lisans, doktora tezleri ile doçentlik ve doktora takdim çalışmalarını içeren 1055 tez çalışmasına yer verilmiştir. Çiçek ve Kozak (2012: 734), Anatolia Turizm Araştırmaları Dergisi'nde 19972011 yılları arasında yayımlanan makaleleri üç döneme ayırmış ve bibliyometrik analizi yapmışlardır. Söz konusu dergide 1997-2001 yılları, 72 makale ile en fazla yayın yapılan dönem olmuştur. En çok çalışılan konular ise 1997-2001 yılları arasında genel turizm, 2002-2006 yılları arasında turizm pazarlaması ve 2007-2011 yılları arasında da turizm yönetimi konuları olmuştur. Temizkan ve arkadaşları (2015: 400), Türkçe akademik dergilerde ve ISI Web of Knowledge veri tabanındaki dergilerde sağlık turizmi konulu makalelerin yıllara göre dağılımı, yazar sayısı, dergi adı, derginin yayın alanı gibi parametreler açısından bibliyometrik analizini yapmış ve en fazla çalışmanın 2011 yılında olduğunu, araştırmaların \%57,7'sinin görgül yöntemleri kullandığını ve \%42,3'ünün kavramsal çalışmalar olduğunu tespit etmişlerdir. Şahin ve Acun (2015: 229) ise turist rehberliği konusunda Ulusal Turizm Kongrelerinde (1990-2015) yayımlanan bildirileri incelemiş ve 16 ulusal turizm kongresinde sunulan 680 bildirinin sadece 22'sinin turist rehberliği konularını içerdiğini ifade etmiştir. En fazla çalışılan konunun ise eğitim alanı konuları olduğunu ayrıca en çok bildirinin 15. Ulusal Turizm Kongresi'nde yayımlandığını ifade etmişlerdir. Aydın (2017: 36) ise yiyecek içecek konusunda yayımlanan tezler üzerine çalışmıştır. 1988-2013 yılları arasında yayımlanan tezlerin genellikle yüksek lisans düzeyinde olduğu, tezlerin en çok turizm işletmeciliği anabilim dalında hazırlandığı ve işletme ile gıda mühendisliği anabilim dallarının da ikinci ve üçüncü sırayı aldığı belirtilmiştir. Kozan ve arkadaşları (2014: 126) ise deniz turizmi ile ilgili yapılan akademik çalışmaları araştırmıştır. Bu bağlamda, 1988 yılından itibaren deniz turizmi konusunda yapılan çalışmalar incelenmiş ve literatürde tez, makale, bildiri kitaplar içerisinde deniz turizmi ile ilgili en çok yapılan yayın türü makale olmuş sırasıyla bildiri ve tez şeklinde devam etmiştir. Deniz turizmi konusunda hazırlanan tez sayısının 
oldukça düşük olduğu ve yat turizmi dışındaki konuları araştıran tezlerin tüm yayınlar içinde \%14'lük bir dilimi kapsadığı tespit edilmiştir.

\section{YÖNTEM}

$\mathrm{Bu}$ çalışmada inanç turizmi ile ilgili yayımlanan çalışmaların bibliyometrik analizi yapılmıştır. Bu çalışmanın amacı inanç turizmi ile ilgili yapılan ulusal bilimsel araştırmaların çeşitli parametreler açısından bibliyometrik analizinin yapılıp bulguların ortaya konmasıdır. Bu çalışma ile inanç turizmine ilişkin ulusal çalışmaların mevcut durumunun ortaya konmasının yanında ileride bu alanda çalışmak isteyen araştırmacılara 1şık tutacağı düşünülmektedir.

Çalışmanın evrenini ulusal literatürde inanç turizmi konusunu ele alan bilimsel çalışmalar oluşturmaktadır. Bilimsel araştırmalara ulaşabilmek için veri tabanı kullanılmıştır. Araştırmada, internet ortamında paylaşılmayan bilimsel çalışmalara ulaşılamaması nedeni ile evrenin hepsine ulaşmak mümkün olmamıştır. Bu durum çalışmanın kısıtlarından biridir. Bu anlamda bilimsel çalışmaların yüklendiği Yükseköğretim Kurulu Akademik Arama (akademik.yok.gov.tr) veri tabanı, araştırma verilerini elde etmek için kullanılmıştır. Bu veri tabanının kullanılmasının nedeni araştırmacıların yayınlarını büyük oranda paylaştığı bir veri tabanı olması yanında Yükseköğretim Kurulu tarafından kurulan akademik çalışmaların yüklendiği resmi bir veri tabanı olmasıdır. Araştırma akademik.yok.gov.tr internet sitesi üzerinden yapılmış ve tarama bölümüne "inanç turizmi" anahtar kelimesi Türkçe ve İngilizce dillerinde yazılmış ve taranmıştır. Veri tabanında herhangi bir yıl sınırlaması yapılmamıştır. Çalışmanın bir diğer önemli kısıtlarından biri ise araştırmaya 01.12.201931.12.2019 tarihleri arasında ulaşılan çalışmaların dahil edilmesidir. Yapılan araştırmada 194 bildiri, 84 makale ve 48 tez olmak üzere toplam 326 yayına ulaşılmıştır. Ancak veri tabanına yüklenen her bildiride tam metine ulaşılamamıştır. Konuya ilişkin bildirilerin tam metinlerine ulaşılamaması sebebiyle bildiriler bibliyometrik analize dahil edilmemiştir. Ayrıca veri tabanındaki 84 makalenin 25 adeti veri tabanında tekrar ettiği için bu makaleler çalışmaya bir kez dahil edilmiş ve 7 makalenin ise tam metnine ulaşılamamış bu durumda araştırmaya 52 adet makale dahil edilmiştir. Yayımlanan 48 tezin ise 2 adeti ileriki bir tarihte yayımlanacağ 1 için 46 adet yüksek lisans ve doktora tezine ulaşılmıştır. Veriler istatistik programına girilmiş ve çalışmada verilerin frekans analizi ve yüzdelik dilimleri hesaplanarak bibliyometrik analiz gerçekleştirilmiştir. Bu çalışmada araştırmaların; yıllara göre dağılımı, yazarın bağlı bulunduğu kurum, araştırma alanı, araştırmanın türü, araştırmanın yaklaşımı, araştırma konusu, araştırma tasarımı ve yöntemi, veri toplama teknikleri, örneklem grubu, örneklem seçme yöntemi ve araştırma analizleri açısından bibliyometrik analizi yapılmıştır.

\section{BULGULAR}

Yapılan çalışmalar sonucunda, 52 makale ve 46 tez olmak üzere toplam 98 bilimsel çalışma analize tabi tutulmuştur. İnanç turizmi ile ilgili lisansüstü tezler içerisinden yüksek lisans tez sayısı 44 iken doktora tezi sayısı sadece 2 adettir. Makalelerin ise 50 adeti Türkçe dilinde yazılırken yalnızca 2 adeti İngilizce dilinde yazılmıştır.

Şekil 1'de inanç turizmine ilişkin ulusal makale ve tezlerin yıllara göre dağılımı yer almaktadır. Buna göre, 7 makale ve 12 tez ile en çok makale ve tezin 2019 yılında yayımlandığı anlaşılmaktadır. Yıllara göre dağılım tablosu incelendiğinde, 1998-2008 yılları arasında sadece 7 makale ve 2 tezin yayımlandığı görülmektedir. Yıllara içerisinde çalışmaların her yıl süreklilik göstermediği anlaşılmaktadır. Ancak son yıllarda inanç turizmi ile ilgili yapılan çalışmalarda bir artış olduğu söylenebilir. 


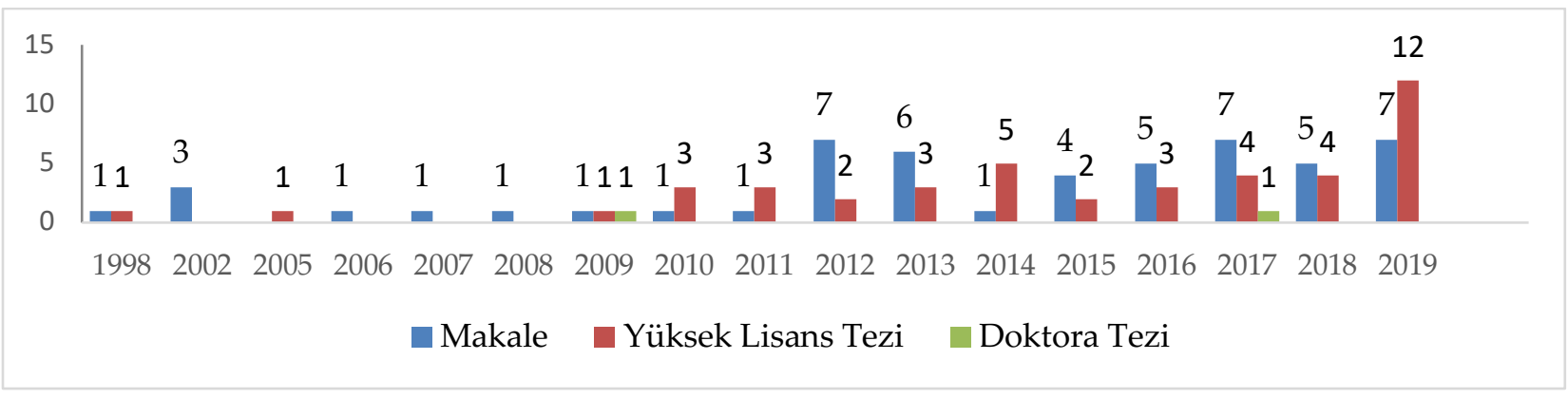

Şekil 1. İnanç Turizmi Kavramını İçeren Çalışmaların Yıllara Göre Dağılımı

İnanç turizmi kavramını araştıran yazarların çalıştıkları kurumların incelendiği Şekil 2'de, yayımlanan makaleler içerisinde en çok yayın yapan üniversitenin 11 makale ile Necmettin Erbakan Üniversitesi olduğu, en çok tez yayımlayan üniversitelerin ise 5'er tez ile Gazi Üniversitesi ve Kastamonu Üniversitesi olduğu anlaşılmaktadır. Necmettin Erbakan Üniversitesi'nin Konya'da bulunması ve bu bölgede dini eserler ve müzeler gibi inanç merkezlerinin olması nedeniyle inanç turizmine yönelik çalışmalara bu durumun yansıdığı söylenebilir. Ayrıca inanç turizmine ilişkin en çok tez yayımlayan üniversitelerin Ankara ve Kastamonu'da bulunması da dikkat çekmektedir. İnanç turizmine yönelik çalışmaların bu illerde yayımlanmasında, kum deniz güneş üçlüsü çerçevesinde hizmet sunan kitle turizm hareketlerinin olmaması ancak inanç ve kutsal yerlerin bulunmasının etkili olduğu düşünülebilir.

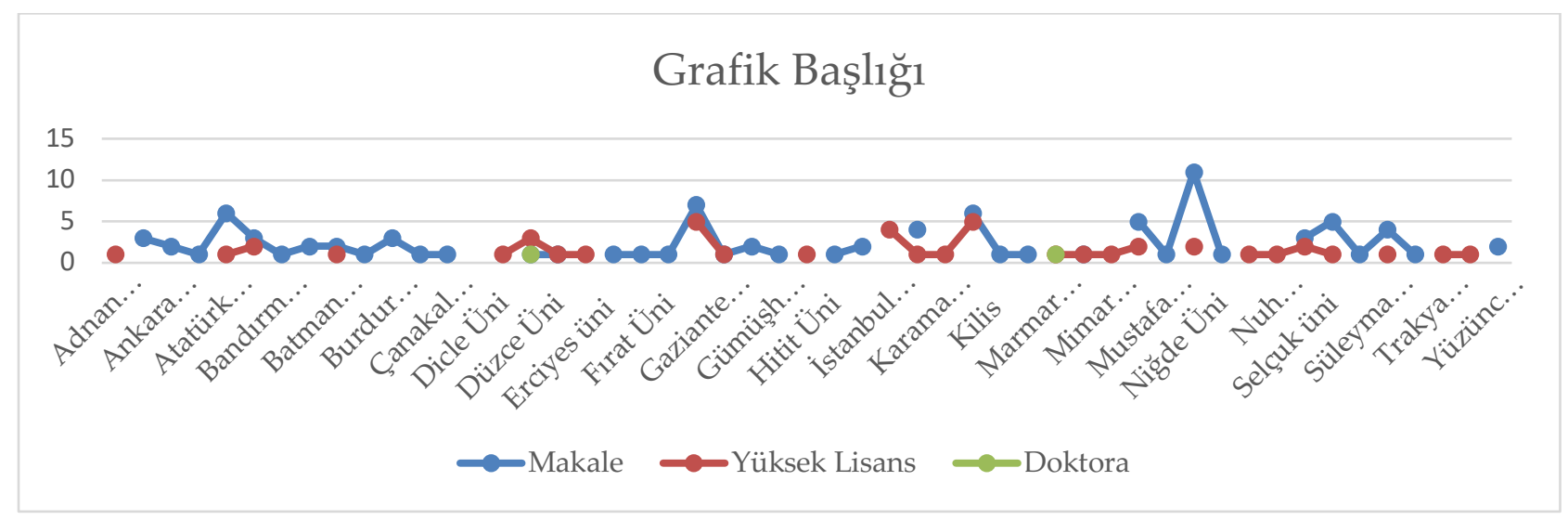

Şekil 2. İnanç Turizmi Kavramını Araştıran Yazarların Çalıştıkları Kurumlar

Tablo 1'de çalışma alanlarına göre incelenen inanç turizmi araştırmalarında 34 makale $(\% 65,4)$ ve 36 tez $(\% 78)$ ile en çok tercih edilen çalışma alanının turizm olduğu görülmektedir. Makaleler değerlendirildiğinde, turizm alanından sonra sırasıyla 8 makale $(\% 15,4)$ ile coğrafya ve 2 'şer makale $(\% 3,85)$ ile sosyoloji, pazarlama ve ilahiyat alanlarında da çalışma yapıldığı anlaşılmaktadır. Bunun yanında, tezler incelendiğinde, turizm alanından sonra en çok çalışma yapılan ikinci alan 3 makale (\%7) ile coğrafya alanı olmuştur. Turizm alanı dışında yoğunlukla çalışılan başka bir alanın olmadığı görülmekte diğer alanlar tarafından yapılan çalışmaların kısmen az olduğu anlaşılmaktadır. İnanç turizminin temel araştırma alanının turizm olmasından dolayı turizm alanı çalışmalarının fazla olduğu ifade edilebilir. 
Tablo 1. İnanç Turizmi Kavramını İçeren Çalışmaların Alanlarına Göre Dağılımı

\begin{tabular}{|l|c|c|c|c|}
\hline Çalışma Alanı & Makale Sayısı & $\mathbf{\%}$ & Tez Sayısı & $\%$ \\
\hline Turizm & 34 & 65,4 & 36 & 78 \\
\hline Coğrafya & 8 & 15,4 & 3 & 7 \\
\hline Sosyoloji & 2 & 3,85 & - & - \\
\hline Pazarlama & 2 & 3,85 & - & - \\
\hline İlahiyat & 2 & 3,85 & - & - \\
\hline Halkla İlişkiler ve Reklam & 1 & 1,92 & - & - \\
\hline Eğitim & 1 & 1,92 & - & - \\
\hline İktisat & 1 & 1,92 & - & - \\
\hline Mimarlık & 1 & 1,92 & 1 & 2 \\
\hline Kültürel Miras & - & - & 2 & 4 \\
\hline Sanat Tarihi & - & - & 1 & 2 \\
\hline Felsefe ve Din & - & - & 1 & 2 \\
\hline Maliye ve Ekonomi & - & - & 1 & 2 \\
\hline Üretim Yönetimi & - & - & 1 & 2 \\
\hline Toplam & 52 & 100 & 46 & 100 \\
\hline
\end{tabular}

Tablo 2. İnanç Turizmi Kavramını İçeren Çalışmaların Araştırma Yaklaşımının Yıllara Göre Dağılımı

\begin{tabular}{|c|c|c|c|c|c|c|c|c|}
\hline $\begin{array}{c}\text { Çalışmaların } \\
\text { Yayımlandığı } \\
\text { Yıl }\end{array}$ & $\begin{array}{c}\text { Görgül } \\
\text { Araştırma } \\
\text { Sayısı }\end{array}$ & $\%$ & $\begin{array}{c}\text { Kavramsal } \\
\text { Araştırma } \\
\text { Sayısı }\end{array}$ & $\%$ & $\begin{array}{c}\text { Görgül } \\
\text { Araştırma } \\
\text { Sayısı }\end{array}$ & $\%$ & $\begin{array}{c}\text { Kavramsal } \\
\text { Araştırma } \\
\text { Sayısı }\end{array}$ & $\%$ \\
\hline 2019 & 5 & 15 & 2 & 11 & 11 & 28 & 1 & 17 \\
\hline 2018 & 4 & 12 & 1 & 6 & 4 & 10 & - & - \\
\hline 2017 & 5 & 15 & 2 & 11 & 4 & 10 & 1 & 17 \\
\hline 2016 & 4 & 12 & 1 & 6 & 3 & 8 & - & - \\
\hline 2015 & 4 & 12 & - & - & 2 & 5 & - & - \\
\hline 2014 & 1 & 3 & - & - & 5 & 13 & - & - \\
\hline 2013 & 2 & 6 & 4 & 22 & 2 & 5 & 1 & 17 \\
\hline 2012 & 6 & 18 & 1 & 6 & 2 & 5 & - & - \\
\hline 2011 & 1 & 3 & - & - & 3 & 8 & - & - \\
\hline 2010 & - & - & 1 & 6 & - & - & 3 & 50 \\
\hline 2009 & 1 & 3 & - & - & 2 & 5 & - & - \\
\hline 2008 & - & - & 1 & 6 & - & - & - & - \\
\hline 2007 & - & - & 1 & 6 & - & - & - & - \\
\hline 2006 & - & - & 1 & 6 & - & - & - & - \\
\hline 2005 & - & - & - & - & 1 & 3 & - & - \\
\hline 2002 & - & - & 3 & 17 & - & - & - & - \\
\hline 1998 & 1 & 3 & - & - & 1 & 3 & - & - \\
\hline Toplam & 34 & 100 & 18 & 100 & 40 & 100 & 6 & 100 \\
\hline & & & & & & & & \\
\hline
\end{tabular}

Tablo 2' de ise inanç turizmi kavramını içeren çalışmaların araştırma yaklaşımlarına göre dağılımına yer verilmiştir. Tabloya göre, makaleler içerisinde görgül çalışmalar arasında 1998 yılından 2011 yılına kadar yalnızca inanç turizmine ilişkin $3(\% 9)$ makale bulunmakta iken son yıllarda görgül çalışmalarda bir artış olduğu söylenebilir. İnanç turizmine ilişkin görgül araştırmaların \%91'i 2012 yılından itibaren yayımlanmış ve bir artı̧̧ eğilimi göstermiştir. Kavramsal çalışmalarda, görgül çalışmalar gibi her yıl istikrarlı bir artışın olmadığı anlaşılmaktadır. Kavramsal çalışmaların görgül çalışmalara oranla daha 
az sayıda olduğu görülmektedir. Yayımlanan 46 tez içerisinde ise görgül çalışmaların sayısı 40 iken, kavramsal araştırma sayısı sadece 6 olarak bulunmuştur. Tezlerin görgül çalışmaları içerisinde 2019 yılı 11 (\%28) adet tez ile en çok görgül araştırma yapılan yıl olmuştur. Kavramsal araştırmaların ise oldukça az sayıda ( 6 adet) olduğu bulunmuştur.

İnanç turizmine ilişkin literatür derlemesini içeren ve kavramsal olarak inanç turizmini inceleyen çalışmaların var olması inanç turizminin sadece turizm konu başlığı altında toplanmadığı coğrafya, mimarlık ve sanat tarihi gibi farklı disiplinler tarafından da araştırıldığı sonucuna ulaşılabilir.

İnanç turizmi kavramını içeren makale ve tezlerin araştırma konularına göre dağılımının incelendiği Tablo 3'te, makaleler içerisinde en çok yayın yapılan araştırma konusunun 11 (\%21) makale ile dini yerlerin inanç turizmi kapsamında değerlendirilmesi üzerine olduğu, tezde ise yayın yapılan konuların başında inanç turizmine yönelik yerel halkın bakış açısı (\%15) ile bölgenin inanç turizmi potansiyeli (\%15) konuları olduğu görülmektedir. Tezlerde ayrıca inanç turizmi ve destinasyon pazarlaması (\%11) ile inanç yerlerini ziyaret edenlerin algısı (\%11) üzerine de çalışmaların yapıldığı sonucu çıkarılmaktadır. Tabloda görüldügüü üzere inanç turizmine ilişkin çalışmalar sadece turizm konu başlıkları altında toplanmamış diğer bilim dalları ve disiplinler (sanat tarihi, mimarlık, coğrafya vb.) tarafından da az sayıda da olsa çalışmalar yer almaktadır.

Tablo 3. İnanç Turizmi Kavramını İçeren Çalışmaların Araştırma Konularına Göre Dağılımı

\begin{tabular}{|c|c|c|c|c|}
\hline Araştırma Konusu & $\begin{array}{c}\text { Makale } \\
\text { Sayısı }\end{array}$ & $\%$ & $\begin{array}{c}\text { Tez } \\
\text { Sayısı }\end{array}$ & $\%$ \\
\hline Dini Yerlerin İnanç Turizmi Kapsamında Değerlendirilmesi & 11 & 21 & 3 & 7 \\
\hline İnanç Turizmine Yönelik Yerel Halkın Bakış Açısı & 7 & 13 & 7 & 15 \\
\hline Bölgenin İnanç Turizmi Potansiyeli & 5 & 10 & 7 & 15 \\
\hline Bölgenin İnanç Turizmi Potansiyeli ve Bölgesel Kalkınma & 5 & 10 & 2 & 4 \\
\hline Kültür Varlıkları ve İnanç Turizmi & 4 & 8 & 1 & 2 \\
\hline İnanç Turizmi ve Destinasyon Pazarlaması & 2 & 4 & 5 & 11 \\
\hline İnanç Yerlerini Ziyaret Edenlerin Algısı & 2 & 4 & 5 & 11 \\
\hline İnanç Turizmi ve Coğrafya & 2 & 4 & - & - \\
\hline İnanç Turizmi ve Öğrencilerin Bakış Açısı & 2 & 4 & - & - \\
\hline İnanç Turizmi ve Turistik Ürün Geliştirme/Potansiyeli & 1 & 2 & 4 & 9 \\
\hline Dini Yerleri Ziyaret Edenlerin Müşteri Memnuniyeti & 1 & 2 & 3 & 7 \\
\hline İnanç Turizmi ve Turistlerin Motivasyonları & 1 & 2 & 1 & 2 \\
\hline İnanç Turizmi ve Sosyoloji & 1 & 2 & 1 & 2 \\
\hline İnanç Turizmi ve Türkiye’deki İnanç Yerleri & 2 & 4 & - & - \\
\hline İnanç Turizmi Seyahat Acentalarının Pazarlama Faaliyetleri & - & - & 2 & 4 \\
\hline $\begin{array}{l}\text { İnanç Turizmi ve Sosyal Medya, İnanç Turizmi Seyahati, } \\
\text { İnanç Turizmi Ziyaretçi Yönetimi, Popüler Kültür ve İnanç } \\
\text { Turizm, İnanç Turizmi Kültür ve Kentsel Turizm, İsa'nın } \\
\text { Doğumu ve İkonografi* }\end{array}$ & 6 & 12 & - & - \\
\hline $\begin{array}{l}\text { İnanç Turizmi ve Eser Tasvirleri, İnanç Turizmi Hizmet } \\
\text { Kalitesi, Turizm Yazınında İnanç Etkinlikleri, İnanç Turizmi } \\
\text { ve Kentsel Sit Alanları, İnanç Turizmi ve Bütünleşik } \\
\text { Pazarlama* }\end{array}$ & - & - & 5 & 11 \\
\hline Toplam & 52 & 100 & 46 & 100 \\
\hline
\end{tabular}

*Her bir araştırma konusundan bir çalışma bulunmaktadır.

Tablo 4'te inanç turizmini içeren makale ve tezlerin araştırma yöntemlerine göre dağılımına yer verilmiştir. Tabloda görüleceği üzere, makalelerde en çok tercih edilen araştırma yöntemi nitel araştırma (\%29) olmuştur. Makaleler içerisinde herhangi bir araştırma yöntemi belirlemeyen ve 
kavramsal çalışma olan 18 (35\%) çalı̧̧ma inanç turizmini teorik olarak tartışmıştır. Kavramsal çalışmalardan sonra en çok tercih edilen üçüncü araştırma türü ise $12(\% 23)$ makale ile nicel araştırma yöntemidir. Tez düzeyindeki araştırmalarda ise, 25 (\%54) tezde nicel araştırma yöntemi kullanılırken, $10(22 \%)$ tezde nitel araştırma yöntemi tercih etmiştir. Tezlerin makalelere oranla daha çok nicel araştırma yöntemlerini kullandığı ve daha az sayıda kavramsal çalışmalara yer verdiği anlaşılmaktadır. $\mathrm{Bu}$ anlamda, tezlerde sayısal veriler ile nicel araştırma yöntemleri bölümlerine daha çok ağırlık verildiği varsayımına varılabilir.

Tablo 4. İnanç Turizmi Kavramını İçeren Çalışmaların Araştırma Yöntemlerine Göre Dağılımı

\begin{tabular}{|l|c|c|c|c|}
\hline & Makale Sayısı & $\mathbf{\%}$ & Tez Sayısi & \% \\
\hline Nicel & 12 & 23 & 25 & 54 \\
\hline Nitel & 15 & 29 & 10 & 22 \\
\hline Karma Yöntem & 7 & 13 & 5 & 11 \\
\hline Kavramsal & 16 & 31 & 6 & 13 \\
\hline $\begin{array}{l}\text { Yöntem Yok (Diğer disiplinler } \\
\text { tarafından yapılan çalışmalar.) }\end{array}$ & 2 & 4 & - & - \\
\hline Toplam & 52 & 100 & 46 & 100 \\
\hline
\end{tabular}

Çalışmaların araştırma tasarımlarına göre dağılımı tablo 5 'te verilmiştir. Tabloya göre, makaleler içerisinde, herhangi bir araştırma yöntemi kullanılmayan 16 kavramsal araştırmanın dışındaki çalışmaların görgül çalışma olmasına rağmen araştırma tasarımına büyük ölçüde değinilmediği söylenebilir. Genellikle, araştırma tasarımından ziyade veri toplama yöntemleri açılanmıştır. Makaleler içerisinden, 10 (\%19) nicel ve 13 (\%25) nitel çalışmanın araştırma yöntemi belirtilmiş ancak araştırma tasarımından bahsedilmemiştir. Aynı şekilde tezlerin 9 (\%20) nitel ve 23 (\%50) nicel çalışmasının araştırma yöntemi belirlenmiş ancak araştırma tasarımından bahsedilmemiştir. Böylelikle 52 makale içerisinden $30(\% 58)$ makalenin ve 46 tez içerisinden $34(\% 74)$ tezin araştırma tasarımından bahsetmediği tespit edilmiştir. Ayrıca, nicel araştırma tasarımları arasından tarama, keşfedici ve betimsel tasarım kullanılmıştır. Nitel araştırmalar içerisinden örnek olay (durum) ve olgu bilim (fenomenoloji) tasarımları kullanılmıştır.

Tablo 5. İnanç Turizmi Kavramını İçeren Çalışmaların Araştırma Tasarımına Göre Dağılımı

\begin{tabular}{|l|c|c|c|c|}
\hline & $\begin{array}{c}\text { Makale } \\
\text { Sayısı }\end{array}$ & $\mathbf{\%}$ & Tez Sayısı & $\%$ \\
\hline Tasarım Belirtilmemiş. & 30 & 58 & 34 & 74 \\
\hline Betimsel Tasarım & 2 & 4 & 3 & 7 \\
\hline Tarama Tasarımı & 1 & 2 & 3 & 7 \\
\hline Keşfedici ve Betimsel Tasarım & 1 & 2 & - & - \\
\hline Örnek Olay (Durum) Tasarım & 1 & 2 & - & - \\
\hline Olgu Bilim (Fenomenoloji) Tasarım & 1 & 2 & - & - \\
\hline Kavramsal Çalışma & 16 & 31 & 6 & 13 \\
\hline Toplam & 52 & 100 & 46 & 100 \\
\hline
\end{tabular}

Tablo $6^{\prime}$ da ise makale ve tezlerin veri toplama yöntemleri incelenmiştir. Makale ve tezler değerlendirildiğinde veri toplama yöntemi içerisinde ağırlıklı olarak anket ve mülakat yöntemleri kullanılmıştır. Tezlerde nitel ve nicel çalışmalar öne çıkmış ve en çok tercih edilen veri toplama yöntemi anket (\%54) ve mülakat (\%22) olmuştur. İnanç turizmini içeren makaleler arasında ise 16 (31\%) makale ile en çok kavramsal çalışmaların olduğu gözlemlenirken, 12 (\%23) makalede anket yöntemi ve 8 (\%15) makalede mülakat yöntemi kullanılmıştır. Tezlerin 6 'sında ise herhangi bir veri toplama yöntemi 
kullanılmamıştır. İnanç turizmi çalışmalarının sadece sosyal bilimler alanında ve turizm alt başlı̆̆ında incelenmemesi, coğrafya, mimarlık ve sanat tarihi gibi diğer disiplinler tarafından da çalışılması nedeniyle sosyal bilimlerin veri toplama yöntemlerinden farklı olarak da verilerin derlendiği göz önünde bulundurulmalıdır.

Tablo 6. İnanç Turizmi Kavramını İçeren Çalışmaların Veri Toplama Yöntemine Göre Dağılımı

\begin{tabular}{|l|c|c|c|c|}
\hline & Makale Sayısı & $\mathbf{\%}$ & Tez Sayısı & \% \\
\hline Anket & 12 & 23 & 25 & 54 \\
\hline Mülakat & 8 & 15 & 10 & 22 \\
\hline Doküman & 4 & 8 & - & - \\
\hline Gözlem & 2 & 4 & - & - \\
\hline Anket ve Mülakat & 2 & 4 & 3 & 7 \\
\hline Anket ve Gözlem & 2 & 4 & - & - \\
\hline Anket, Gözlem ve Mülakat & 2 & 4 & 1 & 2 \\
\hline Mülakat ve Doküman & - & - & - & - \\
\hline Bilimsel Haritalama Yön. ve Mülakat & - & - & 1 & 2 \\
\hline Alan Çalışması, Gözlem ve Mülakat & 2 & 4 & - & - \\
\hline Gözlem ve Mülakat & 1 & 2 & - & - \\
\hline Saha çalışması & 1 & 2 & - & - \\
\hline Kavramsal Çalışma & 16 & 31 & 6 & 13 \\
\hline Toplam & 52 & 100 & 46 & 100 \\
\hline
\end{tabular}

Makale ve tezlerin örneklem grubuna göre dağılımının yer verildiği Tablo 7'de, 52 makale içerisinden 8 'inin (\%15) yerel halk örneklemini, 6'sının (\%12) dini yeri ziyaret eden ziyaretçiler örneklemini ve 5 'inin (\%10) ise Turizm İl Müdürlükleri, müzeler, oteller ve resmi raporlar gibi dokümanları kullandığı sonucuna varılmıştır. Aynı şekilde 5 (\%10) makalede örneklem grubuna dair herhangi bir bilgi verilmemiştir. Tabloda, 46 tez içerisinden en çok tercih edilen örneklem grubunun $13(\% 28)$ tez ile dini yerleri ziyaret eden ziyaretçiler örneklemi olmuştur. Sonrasında ise sırasıyla paydaşlar (\%15), yerel halk (\%13), yerel halk ve turist (\%9) ile turistler (\%7) örneklem grubu şeklindedir. Tezler içerisinde \%13'lük bir oranla kavramsal çalışmalara yer vermiş ve herhangi bir uygulama için örneklem grubu belirlenmemiştir.

Makale ve tezlerin örneklem seçme yöntemine göre dağılımı tablo $8^{\prime}$ de sunulmuştur. Tablo $8^{\prime}$ de kavramsal çalışmalar dışındaki ampirik çalışmaların örneklem seçim yöntemi ele alınmıştır. Makalelerin 25 (48\%) çalışmasında ve tezlerin 13 (28\%) çalışmasında örneklem seçim yöntemine ilişkin herhangi bir bilgi verilmemiştir. Ayrıca örneklem grubu kullanılmayan kavramsal makalelerin dışında amaçlı örneklem yöntemi (4\%), basit tesadüfi örneklem yöntemi (6\%), kolayda örnekleme yöntemi $(4 \%)$, kasti (kararsal) örneklem yöntemi (2\%) ve homojen örneklem (2\%) seçme yöntemleri kullanılmıştır.

Tezlerde kullanılan örneklem yöntemleri incelendiğinde ise amaçlı örneklem yöntemi (7\%), basit tesadüfi örneklem yöntemi (11\%), kolayda örneklem yöntemi (17\%), kasti (kararsal) örneklem yöntemi $(2 \%)$, kotalı tesadüfi örneklem yöntemi (2\%), olasılıklı olmayan örneklem yöntemi $(11 \%)$ ve kartopu örneklem (4\%) yöntemi şeklindedir. Tezlerin içerisindeki 5 tezde olasılıklı olmayan örneklem yöntemi kullanıldığı belirtilmiş ancak hangi örneklem sınıflandırılmasından yararlanıldığı ile ilgili bir bilgiye ulaşılamamıştır. 
Tablo 7. İnanç Turizmi Kavramını İçeren Çalışmaların Örneklem Grubuna İlişkin Dağılım

\begin{tabular}{|l|c|c|c|c|}
\hline & $\begin{array}{c}\text { Makale } \\
\text { Sayısı }\end{array}$ & $\%$ & $\begin{array}{c}\text { Tez } \\
\text { Sayısi }\end{array}$ & $\%$ \\
\hline Yerel Halk & 8 & 15 & 6 & 13 \\
\hline Dini Yeri Ziyaret Eden Ziyaretçiler & 6 & 12 & 13 & 28 \\
\hline $\begin{array}{l}\text { Turizm İl Müdürlükleri, Müzeler, Oteller } \\
\text { ve Raporlar }\end{array}$ & 5 & 10 & - & - \\
\hline Bahsedilmemiş & 5 & 10 & - & - \\
\hline Yerel Halk ve Paydaşlar & 2 & 4 & 1 & 2 \\
\hline Öğrenciler & 2 & 4 & - & - \\
\hline $\begin{array}{l}\text { Resmi Raporlar, Yerel halk ve Uzman } \\
\text { Kişiler }\end{array}$ & 2 & 4 & 1 & 2 \\
\hline Paydaşlar & 1 & 2 & 7 & 15 \\
\hline Yerel Halk ve Turist & 1 & 2 & 4 & 9 \\
\hline Turist & 1 & 2 & 3 & 7 \\
\hline Turist ve Paydaşlar & 1 & 2 & 1 & 2 \\
\hline Otel Yöneticisi & 1 & 2 & - & - \\
\hline Yerel Halk ve Gözlem & 1 & 2 & - & - \\
\hline Seyahat Acentaları & - & & 3 & 7 \\
\hline $\begin{array}{l}\text { Dini Yeri Ziyaret Eden Ziyaretçiler ve } \\
\text { Paydaşlar }\end{array}$ & - & & 1 & 2 \\
\hline Kavramsal Çalışma, Örneklem Yok & 16 & 31 & 6 & 13 \\
\hline Toplam & 52 & 100 & 46 & 100 \\
\hline
\end{tabular}

Tablo 8. İnanç Turizmi Kavramını İçeren Çalışmaların Örneklem Seçme Yöntemi Dağılımı

\begin{tabular}{|l|c|c|c|c|}
\hline & $\begin{array}{c}\text { Makale } \\
\text { Sayısı }\end{array}$ & $\mathbf{\%}$ & $\begin{array}{c}\text { Tez } \\
\text { Sayıs }\end{array}$ & $\%$ \\
\hline Örneklem Seçiminden Bahsedilmemiş. & 25 & 48 & 13 & 28 \\
\hline Amaçlı Örneklem & 2 & 4 & 3 & 7 \\
\hline Basit Tesadüfi Örneklem & 3 & 6 & 5 & 11 \\
\hline Kolayda Örneklem Yöntemi & 2 & 4 & 8 & 17 \\
\hline Örneklem Hesaplaması Yapılmı̧ & 2 & 4 & 2 & 4 \\
\hline Kasti (Kararsal) Örneklem & 1 & 2 & 1 & 2 \\
\hline Homojen Örnekleme & 1 & 2 & - & - \\
\hline Kotalı Tesadüfi Örnekleme & - & - & 1 & 2 \\
\hline Olasılıklı Olmayan Örneklem Yöntemi & - & - & 5 & 11 \\
\hline Kartopu Örnekleme & - & - & 2 & 4 \\
\hline Kavramsal Çalısma & 16 & 31 & 6 & 13 \\
\hline Toplam & 52 & 100 & 46 & 100 \\
\hline
\end{tabular}

Makale ve tezlerde kullanılan analiz yöntemleri Tablo 9' da sunulmuştur. Makalelerde en çok kullanılan analiz yöntemleri 11 (13\%) makalede kullanılan frekans analizi ve geçerlilik-güvenilirlik analizleri olup tezler içerisinde en çok kullanılan analiz ise $24(20 \%)$ tezde kullanılan geçerlilik ve güvenilirlik analizidir. Nitel analizler açısından değerlendirildiğinde ise en çok kullanılan analiz yöntemi 5 makalede kullanılan Swot analizi olurken tezler arasından en çok kullanılan nitel analizin betimleme analizi olduğu anlaşılmaktadır. İnanç turizmi araştırmalarında temel düzeyde istatistiki analizlerin kullanıldığı ve ileri düzey istatistik analizlere çok fazla yer verilmediği söylenebilir. Bu anlamda 
gelecekteki çalışmalarda ileri düzey analiz yöntemleri kullanılarak yapılan çalışmalar ile inanç turizmine yönelik derinlemesine araştırmaların yapılması önerilebilir.

Tablo 9. İnanç Turizmi Kavramını İçeren Çalışmalarda Kullanılan Analizlere Göre Dağılım

\begin{tabular}{|c|c|c|c|c|}
\hline & Makale Sayısı & $\%$ & Tez Sayısı & $\%$ \\
\hline Frekans Analizi & 11 & 12,6 & 17 & 13,8 \\
\hline Geçerlilik ve Güvenilirlik Analizi & 11 & 12,6 & 24 & 19,5 \\
\hline Açıklayıcı Faktör Analizi & 6 & 6,9 & 11 & 8,9 \\
\hline Tek Yönlü Varyans Analizi & 5 & 5,7 & 17 & 13,8 \\
\hline Swot Analizi & 5 & 5,7 & 4 & 3,3 \\
\hline T-Testi & 4 & 4,6 & 15 & 12,2 \\
\hline Mann Whitney U Testi & 4 & 4,6 & 1 & 0,8 \\
\hline Kruskall Wallis Testi & 4 & 4,6 & 1 & 0,8 \\
\hline Bahsedilmemiş & 9 & 10,3 & 5 & 4,1 \\
\hline Betimleme Analizi & 2 & 2,3 & 5 & 4,1 \\
\hline İçerik Analizi & 2 & 2,3 & 3 & 2,4 \\
\hline Tukey Hsd Testi & 2 & 2,3 & - & - \\
\hline Ki-Kare Bağımsızlık Testi & 1 & 1,1 & 7 & 5,7 \\
\hline LSD Post Hoc Çoklu Karşılaştırma Test, & 1 & 1,1 & 3 & 2,4 \\
\hline Korelasyon Analizi & 1 & 1,1 & 2 & 1,6 \\
\hline Tamhane's T2 Çoklu Karşılaştırma Test, & 1 & 1,1 & - & - \\
\hline Kolmogorov-Smirnov/ Shapiro-Wilk Testi & 2 & 2,3 & 1 & 0,8 \\
\hline $\begin{array}{l}\text { Regresyon Analizi, Bibliyometrik Analiz, Ayırma } \\
\text { Analizi, Doküman Analizi, İç ve Dış Çevre Analizi }\end{array}$ & - & - & 1 & 0,8 \\
\hline Kavramsal Çalışma Analiz Yok & 16 & 18,4 & 6 & 4,9 \\
\hline Toplam & 87 & 100 & 123 & 100 \\
\hline
\end{tabular}

YÖK Akademik Arama veri tabanında yer alan inanç turizmine ilişkin bilimsel yayınların incelenmesi sonucunda, 2012 yılından itibaren inanç turizmine yönelik araştırmalarda bir artış olduğu görülmektedir. İnanç turizmi ile ilgili makalelerin $\% 65,4^{\prime} \ddot{u}$ ve tezlerin $\% 78^{\prime} \mathrm{i}$ turizm alanında yapılan çalışmalar olmuştur. Ayrıca, yayınlanan 52 makalenin \%65'i görgül çalışmalardan oluşurken, 46 tez içerisinde görgül çalışma oranı \%87'i şeklindedir. Özetle, inanç turizmi konusunun son yıllarda daha fazla araştırıldığı ve söz konusu çalışmaların büyük oranda görgül çalışmalardan oluştuğu sonucuna ulaşılmıştır. İnanç turizmi, temel olarak turizm alanının bir konusu olması nedeniyle genellikle turizm alanındaki araştırmacılar tarafından incelenmiş ancak sanat tarihi, mimarlık ve coğrafya bilim dalları tarafından da incelenen bir konu olmuştur. Çalışmaların araştırma yöntemlerinin incelenmesinde ise, makalelerde genellikle nitel araştırma yönteminin tercih edildiği ancak araştırma tasarımından bahsedilmediği sonucuna ulaşılmıştır. Tezlerde ise genellikle nicel araştırma yöntemleri tercih edilirken yine araştırma tasarımından bahsedilmemiştir. Benzer şekilde araştırmaların örneklem grubu seçme yöntemlerinden bahsedilmediği anlaşılmaktadır. Tezlerde bu oranın daha düşük olmasında tezlerin genellikle keşfedici olduğu ve konu ile ilgili problemlere cevap aramak amaciyla örneklem grubu seçimine dikkat edildiği düşünülmektedir. Bu bağlamda, tezlerin araştırma süreçlerinin makalelere oranla tam ve doğru bir şekilde tamamlandığı ve bilimsel araştırma yöntemlerinin gerekliliklerinin yerine getirildiği söylenebilir. 


\section{SONUÇ}

İnanç turizmi, kitlesel turist hareketlerinden ayrı olmasına rağmen hac da dahil olmak üzere inanç ile güdülenmiş seyahatler açısından motive edici güç haline gelmiştir (Henderson, 2011: 542). İnanç turizmi son elli yıl içerisinde büyük bir oranda artmış ve dikkat çekici turizm türlerinden biri olmuştur. Dolayısıyla inanç turizmine yönelik araştırmaların yapılması sonucu inanç turizmine katılan turistlerin seyahat motivasyonlarının inanç turizmi için itici bir güç olduğu ifade edilmektedir (Fodness, 1994: 557). Bu çalışmada, son yıllarda ulusal literatürde araştırılan inanç turizmi kavramına ilişkin çalışmaların bibliyometrik özellikleri değerlendirilmiştir.

Çalışmada inanç turizmi kavramı ile ilgili araştırmaların; yıllara göre dağılımı, yazarın bağlı bulunduğu kurum, araştırma alanı, araştırmanın türü, araştırmanın yaklaşımı, araştırma konusu, araştırma tasarımı ve yöntemi, veri toplama teknikleri, örneklem grubu ve seçme yöntemi ile araştırma analizleri incelenmiştir. Bu bağlamda Yükseköğretim Kurulu Akademik Arama veri tabanı üzerinden yayımlanan makale ve tezler çeşitli parametreler açısından incelenmiştir. Çalışmada, 52 makale ve 46 teze ulaşılmıştır. Çoğu bildirinin tam metnine ulaşılamadığı ve özet metinlerinden her parametre için yeterli bilgiye erişilemediği için bildiriler bu çalışmaya dahil edilmemiştir.

Yapılan çalışma ile inanç turizmine ilişkin makale ve tez çalışmalarının 1998 yılından itibaren başladığı ve 2012 yılından itibaren çalışmaların giderek arttığı anlaşılmaktadır. Yayımlanan 52 makalenin 16'sı kavramsal çalışma olurken 46 tez içerisinden 6 tezin kavramsal çalışma olduğu belirlenmiştir. Makale açısından değerlendirildiğinde 2012 yılından itibaren makalelerin sayısında bir artış olduğu gözlemlenirken, en fazla turizm alanında araştırma yapıldığı ve nicel ile nitel araştırma yöntemleri yaklaşımlarını kullanım sıklığının birbirine yakın olduğu belirlenmiştir. Ayrıca makaleler incelendiğinde en çok araştırılan konunun dini yerlerin inanç turizmi kapsamında değerlendirilmesi üzerine olduğu ve en çok tercih edilen örneklem grubunun ise yerel halk olduğu belirlenmiştir. Veri toplama teknikleri açısından ise en çok anket ve mülakat tekniğinden yararlanılmıştır. Makaleler içerisinde nitel çalışmaların nicel çalışmalardan daha fazla olduğu sonucuna ulaşılmıştır. Bu durum Arslan ve Emeksiz (2016: 6) tarafından konaklama işletmelerinde çevre yönetimi konulu makalelerin bibliyometrik analizi sonucunda elde edilen ulusal makaleler ile ilgili veriyle benzerlik göstermektedir. İnanç turizmi ve çevre yönetimi gibi ulusal literatürde çok fazla çalışılmamış konularda nitel bir yaklaşım ile olgunun anlaşılmasının ve kavramsallaşmasının sağlandığı düşünülebilir. Diğer bir ifade ile yorumsamacı bir anlayış ile problemlerin arkasındaki nedenleri anlamaya ve empati yapmaya önem vererek olguların doğal ortamında gözlemlenmesine çalışıldığı düşünülmektedir (Gürbüz ve Şahin, 2018: 35). Ayrıca makalelerin çoğunda araştırma tasarımının ve örneklem seçme yönteminin belirtilmediği bulgusuna ulaşılmıştır. Bu durumun nedeninin araştırma tasarımının genellikle iki farklı anlamda kullanılması olduğu düşünülmektedir. Araştırma tasarımı bazı çalışmalarda kullanılacak temel araştırma yöntem veya deseni (Örnek olay yöntemi, deneysel araştırma gibi) ifade etmek için kullanılırken bazı çalışmalarda araştırma sürecinde kullanılacak araştırma stratejilerinin (nitel, nicel veya karma yöntem gibi) belirlenmesi anlamında kullanılmıştır. Ayrıca, örneklem, veri toplama yöntemi ve veri analiz tekniklerinin belirlenmesini dahi kapsayacak bir anlamda ifade edilmiştir (Gürbüz ve Şahin, 2018: 98). Bir diğer bulgu ise makalelerde en çok kullanılan analiz yönteminin frekans analizi ile geçerlilik ve güvenirlik analizi olduğu belirlenmiştir. Araştırmalarda temel düzeyde istatistik analizlerinin kullanıldığı ilerideki çalışmalarda ileri düzey istatistik analizleri kullanılarak değişkenler arasındaki ilişkilerin daha derin araştırılması sağlanabilir.

Tezler incelendiğinde ise 46 tez içerisinde yalnızca 2 adet doktora tezi yayımlanmışken 44 adet yüksek lisans tezi yayımlanmıştır. Sünnetçioğlu ve arkadaşları (2017: 350) da gastronomi alanında yayımlanan tezleri inceleyerek genellikle tezlerin yüksek lisans düzeyinde yayımlandığı sonucuna varmıştır. $\mathrm{Bu}$ çalışma ile de benzer sonuçlar elde edilmiştir. Aynı şekilde birçok çalışmada da yüksek lisans tezlerinin doktora tezlerinden daha fazla olduğu sonucuna ulaşılmıştır (Çolakoğlu vd., 2019: 138; Oğuzbalaban, 2019: 1018; Tayfun vd., 2018: 532; Alımanoğlu ve Ayazlar, 2017: 8 Demirbulat ve Dinç, 2016: 25). 
Tezler içerisinde en fazla yayın yapılan yılın ise 2019 yılı olduğu, en fazla tezin 5'er tez ile Gazi Üniversitesi ve Kastamonu Üniversitesi tarafından yayımlandığı, araştırma yöntemleri içerisinden en çok nicel yöntemin tercih edildiği ve en çok anket yöntemi ile veri toplandığı sonucuna varılmıştır. Ayrıca tezlerin en çok turizm alanından çalışmaları olduğu, inanç turizmine yönelik yerel halkın bakış açısı ile bir bölgenin inanç turizmi potansiyeli konularının en çok araştırılan konular olduğu ve en çok kullanılan örneklem grubunun da dini yeri ziyaret eden ziyaretçiler olduğu sonucuna ulaşılmıştır. Ancak araştırma tasarımının çoğu araştırmada yer almadığı görülmüştür. Benzer şekilde örneklem seçme yönteminin belirtilmediği çalışmaların çoğunlukta olduğu ve en çok kullanılan analizlerin sırasıyla geçerlilik ve güvenirlik analizi, frekans analizi, tek yönlü varyans analizi ve t-tesi olduğu belirlenmiştir.

$\mathrm{Bu}$ çalışma ile inanç turizmi kavramına ilişkin ulusal araştırmalar incelenerek inanç turizminin literatürdeki mevcut durumu değerlendirilmiştir. Ayrıca inanç turizmi alanındaki bibliyometrik bir çalışmanın, ilgili literatürün gelişim sürecini değerlendirmede bir kolaylık sağlayacağı ve ileride bu alanda çalışmak isteyen araştırmacılara katkı sağlayacağı düşünülmektedir. Araştırmada, sadece Yükseköğretim Kurulu Akademik Arama veri tabanında yer alan inanç turizmi çalışmaları incelenmiştir. Gelecekteki çalışmalarda farklı veri tabanları kullanılarak ulusal ve uluslararası literatürde inanç turizmi ile ilgili bir karşılaştırma yapılabilir. Ayrıca inanç turizmi ile ilgili bibliyometrik haritalama yöntemi ile atıf ve ağ grafiği analizleri ile çalışmalar incelenebilir.

\section{KAYNAKÇA}

Albayrak, A. (2013). Kış Turizmi Turistlerinin Seyahat Motivasyonları. 14. Ulusal Turizm Kongresi, Kayseri.

Alecu, I. C. (2010). Epistemological Aspects of Religious Tourism in Rural Areas. International Journal of Business, Management and Social Sciences, 2(3), 59-65.

Alımanoğlu, Ç., ve Ayazlar, G. (2017). Türkiye'de Kırsal Turizm Konulu Lisansüstü Tez Çalışmaları Üzerine Bibliyometrik Bir İnceleme (2003-2016). International Rural Tourism and Development Journal (IRTAD) E-ISSN: 2602-4462, 1(1), 6-12.

Arslan, E., ve Emeksiz, M. (2016). Konaklama İşletmelerinde Çevre Yönetimi Konusunun Bibliyometrik Profili ve Gelecek Çalışmalar İçin Öneriler. Disiplinlerarası Akademik Turizm Dergisi, 1(1), 1-12.

Aydin, B. (2017). Yükseköğretim Kurulu Tez Merkezinde (Yöktez) Yiyecek İçecek İşletmeciliği Alanında Kayıtlı Bulunan Tezlerin Bibliyometrik Analizi. Disiplinlerarası Akademik Turizm Dergisi, 2(1), 23-38.

Barrios, M., Borrego, A., Vilaginés, A., Ollé, C., and Somoza, M. (2008). A Bibliometric Study of Psychological Research on Tourism. Scientometrics, 77(3), 453-467.

Bartolomé, A., Ramos, V., and Rey-Maquieira, J. (2009). Residents' Attitudes Towards Diversification Sports Tourism in the Balearics. Tourism Recreation Research, 34(1), 55-65.

Benur, A. M., and Bramwell, B. (2015). Tourism Product Development and Product Diversification in Destinations. Tourism Management, 50, 213-224.

Bidžan-Gekić, A., Gekić, H., and Žunić, L. (2019). Development of Religious Tourism in West Herzegovina Tourist-Geographic Region. European Researcher. Series A, 10(2), 78-85.

Blackwell, R. (2015). Motivations for Religious Tourism, Pilgrimage, Festivals and Events. (Editor) Raj, R. and Morpeth, N. D.: In Religious Tourism and Pilgrimage Management: An International Perspective. Wallingford: Cabi, 103-17.

Broadus, R. (1987). Toward a Definition Of “Bibliometrics". Scientometrics, 12(5-6), 373-379.

Correia, A., Oom do Valle, P., and Moço, C. (2007). Why People Travel to Exotic Places. International Journal of Culture, Tourism and Hospitality Research, 1(1), 45-61. 
Çiçek, D., ve Kozak, N. (2012). Anatolia: Turizm Araştırmaları Dergisi'nde Yayımlanan Hakem Denetimli Makalelerin Bibliyometrik Profili. Türk Kütüphaneciliği, 26(4), 734-756.

Çolakoğlu, Ü., Altun, H. E., ve Kıykaç, B. (2019). Türkiye'deki Medikal Turizm Tezlerinin Bibliyometrik Profili (2008-2018). Anatolia: Turizm Araştırmaları Dergisi, 30(2), 135-143.

Daim, T. U., Rueda, G., Martin, H., and Gerdsri, P. (2006). Forecasting Emerging Technologies: Use of Bibliometrics And Patent Analysis. Technological Forecasting and Social Change, 73(8), 981-1012.

Demirbulat, Ö. G., ve Dinç, N. T. (2017). Sürdürülebilir Turizm Konulu Lisansüstü Tezlerin Bibliyometrik Profili. Seyahat ve Otel İşletmeciliği Dergisi, 14(2), 20-30.

Farmaki, A. (2012). A Supply-Side Evaluation of Coastal Tourism Diversification: The Case of Cyprus. Tourism Planning \& Development, 9(2), 183-203.

Fodness, D. (1994). Measuring Tourist Motivation. Annals of Tourism Research, 21(3), 555-581.

Gürbüz, S., ve Şahin, F. (2018). Sosyal Bilimlerde Araştırma Yöntemleri. (4. Basım). Ankara: Seçkin Yayıncilik.

Güzel, Ö. (2010). Turistik Ürün Çeşitlendirmesi Kapsamında Yeni Bir Dinamik: İnanç Turizmi. Süleyman Demirel Üniversitesi Vizyoner Dergisi, 2(2), 87-100.

Hall, C. M. (2006). Travel and Journeying on The Sea of Faith: Perspectives from Religious Humanism. (Editor) Timothy, D. and Olsen, D.: In Tourism, Religion and Spiritual Journeys. (pp. 64-77). Routledge.

Hassan, S. H., Zainal, S. R. M., and Mohamed, O. (2015). Determinants of Destination Knowledge Acquisition in Religious Tourism: Perspective of Umrah Travelers. International Journal of Marketing Studies, 7(3), 84-94.

Henderson, J. C. (2003). Managing Tourism and Islam in Peninsular Malaysia. Tourism management, 24(4), 447-456.

Henderson, J. C. (2011). Religious Tourism and Its Management: The Hajj in Saudi Arabia. International Journal of Tourism Research, 13(6), 541-552.

Horng, J. S., Liu, C. H., Chou, H. Y., and Tsai, C. Y. (2012). Understanding the Impact of Culinary Brand Equity and Destination Familiarity on Travel Intentions. Tourism management, 33(4), 815-824.

Hughes, K., Bond, N., and Ballantyne, R. (2013). Designing and Managing Interpretive Experiences at Religious Sites: Visitors' Perceptions of Canterbury Cathedral. Tourism Management, 36, 210-220.

İbiş S., ve Batman, O. (2018). Japonya ve Güney Kore'den İstanbul'a Gelen Turistlerin Seyahat Motivasyonları ve Yeniden Ziyaret Etme Niyeti Üzerine Bir Araştırma. Seyahat ve Otel İşletmeciliği Dergisi, 15(2), 246-262.

Jang, S., Bai, B., Hu, C., and Wu, C. M. E. (2009). Affect, Travel Motivation, and Travel Intention: A Senior Market. Journal of Hospitality and Tourism Research, 33(1), 51-73.

Jiang, Y., Ritchie, B. W., and Benckendorff, P. (2019). Bibliometric Visualisation: An Application in Tourism Crisis and Disaster Management Research. Current Issues in Tourism, 22(16), 1925-1957.

Karagöz, D., ve Kozak, N. (2014). Anatolia Turizm Araştırmaları Dergisi'nin Bibliyometrik Analizi: Araştırma Konuları ve Kurumlar Arası İş Birliğinin Sosyal A $\breve{g}$ Analizi ile İncelenmesi. Türk Kütüphaneciliği, 28(1), 47-61.

Kim, B., Kim, S., and King, B. (2019). Religious Tourism Studies: Evolution, Progress, and Future Prospects. Tourism Recreation Research, 1-19.

Köseoglu, M. A., Sehitoglu, Y., and Parnell, J. A. (2015). A Bibliometric Analysis of Scholarly Work in Leading Tourism and Hospitality Journals: The Case of Turkey. Anatolia, 26(3), 359-371. 
Kozak, N. (1996). Türkiye Turizm Tezleri Bibliyografyası (1952-1995). (1. Basım) Ankara: Anatolia Yayıncilık.

Kozan, Y., Kozan, G. Y., Özdemir, S., Özdemir, S. S., ve Günlü, E. (2014). Turizm Yazınında Deniz Turizmi'nin Olgusal Gelişimi. Dokuz Eylül Üniversitesi Denizcilik Fakültesi Dergisi, 6(2), 115-129.

Lundberg, D. E. (1971). Why Tourists Travel. Cornell HRA Quarterly, February, 64-70.

Oğuzbalaban, G. (2019). Termal Turizm Konulu Lisansüstü Tezlerin Bibliyometrik Analizi, Türk Turizm Araştırmaları Dergisi, 3(4): 1012-1027.

Okumus, B., Koseoglu, M. A., and Ma, F. (2018). Food and Gastronomy Research in Tourism and Hospitality: A Bibliometric Analysis. International Journal of Hospitality Management, 73, 64-74.

Olsen, D. H., and Timothy, D. J. (2006). Tourism and Religious Journeys, (Editor). Timothy D. J., and Olsen, D. H.: In Tourism, Religion and Spiritual Journeys. (pp. 1-21). Routledge.

Özel, Ç. H., ve Kozak, N. (2012). Turizm Pazarlaması Alanının Bibliyometrik Profili (2000-2010) ve Bir Atıf Analizi Çalışması. Türk Kütüphaneciliği, 26(4), 715-733.

Papatheodorou, A. (2001). Why People Travel to Different Places. Annals of Tourism Research, 28(1), 164179.

Pritchard, A. (1969). Statistical Bibliography or Bibliometrics. Journal of Documentation, 25(4), 348-349.

Puşcaşu, V. (2015). Religious Tourism or Pilgrimage. European Journal of Science and Theology, 11(3), 131142.

Rinschede, G. (1992). Forms of Religious Tourism. Annals of Tourism Research, 19(1), 51-67.

Rotherham, I. D. (2007). Sustaining Tourism Infrastructures for Religious Tourists and Pilgrims Within the UK, (Editor) Raj, R. and Morpeth, N.D.: In Religious Tourism and Pilgrimage Festivals Management: An international perspective, (pp. 64-77).

Sánchez, A. D., Del Río, M. D. L. C., and García, J. Á. (2017). Bibliometric Analysis of Publications on Wine Tourism in The Databases Scopus and Wos. European Research on Management and Business Economics, 23(1), 8-15.

Sargın, S. (2006). Yalvaç'ta İnanç Turizmi. Firat Üniversitesi Sosyal Bilimler Dergisi, 16(2), 1-18.

Shackley, M. (2005). Service Delivery at Sacred Sites; Potential Contribution of Management Science. European Journal of Science and Theology, 1(4), 33-40.

Shackley, M. (2006). Empty Bottles at Sacred Sites: Religious Retailing at Ireland's National Shrine, (Editor). Timothy D. J., and Olsen, D. H.: In Tourism, Religion and Spiritual Journeys. (pp. 110-119). Routledge.

Sharpley, R. (2009). Tourism, Religion and Spirituality, (Editor) Jamal, T. and Robinson, M.: In the SAGE Handbook of Tourism Studies, (pp. 237-253).

Sünnetçioğlu, A., Yalçınkaya, P., Olcay, M., ve Mercan, Ş. O. (2017). Turizm Alanında Yazılmış Olan Gastronomiye İlişkin Tezlerin Bibliyometrik Profili. Journal of Tourism and Gastronomy Studies, 5(2), 345354.

Şahin, S., ve Acun, A. (2015). Turist Rehberliği Alanının Bibliyometrik Profili Ulusal Turizm Kongreleri Bildirileri. Balıkesir Üniversitesi Sosyal Bilimler Enstitüsü Dergisi, 18(34), 213-234.

Şenol, F. (2016). Türkiye Turizm Coğrafyası ve Dünya Kültürel Mirası. (5. Basım), Ankara: Detay Yayıncllık, Tala, M. L., and Padurean, A. M. (2008). Dimensions of Religious Tourism. Amfiteatru Economic, 10, 242253. 
Tapur, T. (2009). Konya İlinde Kültür ve İnanç Turizmi. Journal of International Social Research, 2(9), 473492.

Tayfun, A., Ülker, M., Gökçe, Y., Tengilimoğlu, E., Sürücü, Ç., ve Durmaz, M. (2018). Turizm Alanında Yiyecek ve İçecek ile İlgili Lisansüstü Tezlerin Bibliyometrik Analizi. Journal of Tourism and Gastronomy Studies, 6(2), 523-547.

Temizkan, P., Çiçek, D., ve Özdemir, C. (2015). Bibliometric Profile Of Articles Published On Health Tourism Sağllk Turizmi Konusunda Yayınlanan Makalelerin Bibliyometrik Profili. Journal of Human Sciences, 12(2), 394-415.

Unwto, 2011. https://www.e-unwto.org/doi/book/10.18111/9789284413805 (Erişim Tarihi: 01.02.2020)

Verma, M., and Sarangi, P. (2019, August). Modeling Attributes of Religious Tourism: A study of Kumbh Mela, India. In Journal of Convention \& Event Tourism 20(4), 296-324. Routledge.

Vukonić, B. (1998). Religious Tourism: Economic Value or An Empty Box?. Zagreb International Review of Economics \& Business, 1(1), 83-94.

Zencir, E., ve Kozak, N. (2012). Sosyal Bilimler Enstitü Dergilerinde Yayımlanan Turizm Makalelerinin Bibliyometrik Profili (2000-2010). VI. Lisansüstü Turizm Öğrencileri Araştırma Kongresi, 12-15 Nisan 2012, Kemer, Antalya, Ss: 673-682.

Zengin, B. (2006). Turizm Coğrafyası: Türkiye Genel ve Bölgeler Turizm Coğrafyası. (1. Basım). Değişim Yayınları.

Weidenfeld, A. D. I., and Ron, A. S. (2008). Religious Needs in The Tourism Industry. Anatolia, 19(2), 357-361.

Wu, B., Zhu, H., and Xu, X. (2000). Trends in China's Domestic Tourism Development at The Turn of The Century. International Journal of Contemporary Hospitality Management, 12(5), 296-299. 